\title{
DEKONSTRUKSI TAFSIR ANTROPOSENTRISME: Telaah Ayat-Ayat Berwawasan Lingkungan
}

\author{
Junaidi Abdillah \\ IAIN Raden Intan Lampung \\ junaidiabdillah@iainradenintan.ac.id
}

\begin{abstract}
Abstrak
Mainstream yang berkembang bahwa alam semesta ini disediakan oleh Tuhan hanya untuk kemakmuran manusia, membuat eksplorasi atas sumber daya alam ini makin brutal tak terkendali. Agama-agama samawi juga ditengarai kuat menanamkan paham antroposentrisme pada pemeluknya. Sehingga, muncul pandangan bahwa penyebab kerusakan lingkungan dan alam tersebut diakibatkan paham antroposentrisme tersebut. Islam sebagai salah satu agama samawi juga tidak luput dari tudingan tersebut. Karenanya, tulisan ini bermaksud membongkar paradigma tafsir bias antroposentisme dalam Islam. Dengan metode maudu'i, penulis mengumpulkan dan mengelaborasi ayat-ayat berbasis ekologi. Pendekatan yang dipakai adalah bayani dan hermeneutika. Sedangkan content analysis sebagai pisau bedahnya. Tulisan ini bertujuan menemukan pesan-pesan tafsir berbasis lingkungan dalam perspektif ekologi Islam.
\end{abstract}

Abstract

DECONSTRUCTION OF ANTHROPOCENTRISM EXEGESTION: STUDY OF ENVIRONMENTAL VERSES. The growing mainstream that the universe is provided by God only to human prosperity has generated the increasingly brutal and uncontrolable exploration of natural resources. Consequently, celestial religions are also strongly suspected to instill anthropocentrism among its adherents Thus, it is appeared the view that the causes of environmental damages are instigated by anthropocentric understanding. Islam, as one of the celestical religions, is also becoming the target of such accusations. This study is aimed at dismantling the biased paradigm of anthropocentric interpretation in Islam. By using maudu'i - topical- 
methods along with the bayani and hermeneutic approaches, the author collects and elaborates a number of verses in the Qur'an related to ecology to find the true messages of ecological interpretation within the Islamic perspective.

Kata Kunci: Lingkungan; Tafsir; Antroposentrisme; Ekologi.

\section{A. Pendahuluan}

Persoalan lingkungan menjadi tema menarik untuk selalu dikaji ketika kerusakan lingkungan hidup semakin memprihatinkan dari waktu ke waktu. ${ }^{1}$ Fenomena longsor, banjir bandang, gempa bumi, kebakaran hutan seakan sudah menjadi rutinitas musibah. Tak pelak, kajian lingkungan menjadi isu sentral. Namun seiring dengan meredupnya bencana tersebut maka redup pula isu tentang lingkungan. Sehingga kajian-kajian lingkungan seakan menjadi obat sementara bagi musibah-musibah tersebut. Namun akar permasalahan penyebab kerusakan lingkungan hidup tak pernah terurai guna dicarikan solusinya.

Manusia sebagai makhluk mandataris Allah swt di bumi yang diberi kepercayaan (baca: amanah) untuk memelihara dan memakmurkan bumi nampaknya belum memberikan hasil yang terbaik. Khatifah fi al-Ard yang dimaknai dengan manusia sebagai

${ }^{1}$ Kerusakan lingkungan di berbagai belahan bumi telah sampai pada tahapan yang menghawatirkan. Enviromental yang dikeluarkan Worldwatch Institute (2004), menyebutkan bahwa pada 1999 lubang ozon di atas antartika telah mencapai 25 juta kilometer persegi. Luas yang hampir sama dengan Amerika Serikat, China dan India digabung menjadi satu. Lebih lanjut laporan tersebut, dengan mengutip data PBB tahun 2001, menyebutkan negara-negara tropis telah kehilangan hutannya lebih dari 15 juta hektar tiap tahunnya. Tahun 2003 disebutkan bahwa 90 persen ikan-ikan yang bernilai ekonomis telah dibunuh oleh industri perikanan. Di sisi lain, jurang kesenjangan penguasaan sumber daya alam antara mereka yang mampu dengan yang tidak semakin menganga lebar. Tercatat dalam laporan UNEP (2002) seperlima penduduk dunia menghabiskan 90\% dari total konsumsi perorangan global. Sisanya, yang mencakup sekitar 4 miliyar jiwa, hanya mampu bertahan dengan tingkat pendapatan antara \$ 1 hingga \$ 2 setiap harinya. Kurang labih 1,1 milyar penduduk bumi masih kesulitan untuk mendapatkan air bersih dan 2,4 miliar jiwa kesulitan mengakses sarana sanitasi yang sehat. Kebanyakan dari mereka tinggal di kawasan Asia dan Afrika. Lihat dalam Enviromental Milestone oleh Wolrdwatch Institute. Tentang hal ini dapat diakses pada alamat: http//www. worldwatch.org /brain/features/timeline/timeline.html. diunduh pada tanggal 20 Desember 2012. 
wakil Allah di planet bumi seharusnya menjadi titik tolak awal manusia dalam mengelola sekaligus memelihara alam ini. Namun realitas di lapangan justru mandataris ini digunakan dalam batas yang tidak wajar. Sehingga pada gilirannya kemudian manusia dengan dalih membangun bumi justru membuat kerusakan dahsyat bumi ini.

Akar permasalahan krisis lingkungan dan alam disinyalir berawal dari mengakarnya filsafat antroposontrisme dalam jiwajiwa manusia di bumi ini. Antoposentrisme ${ }^{2}$ dimaknai sebagai teori etika lingkungan yang memandang pusat alam semesta adalah manusia. Sehingga kepentingan manusia paling menentukan dalam pengambilan kebijakan berkaitan dengan alam secara langsung atau tidak. $^{3}$

Antroposentrisme diduga kuat berakar pada ajaran agamaagama monotheis termasuk Islam dituduh mengembangkan ajaran tersebut. Toynbee sebagaimana dikutip Martin Harun dalam pengantarbukuAgama Ramah Lingkungan, menegaskan bahwa agamaagama monotheis telah menghilangkan rasa hormat terhadap alam yang Iahi. Sehingga tak ada lagi yang dapat menahan ketamakan manusia. ${ }^{4}$ Islam sebagai salah satu agama monotheis tak luput dari tuduhan serupa. Akar tradisi yang sama yakni agama Ibrahim dan lahir di Timur Tengah mengakibatkan Islam sebagai suatu agama dianggap sama dengan tradisi Yudeo-Kristen dalam mengajarkan antroposentrisme. ${ }^{5}$

${ }^{2}$ Menurut Mujiyono Abdillah, dalam kajian teologilingkungan Islam, terkait dengan hubungan manusia dengan alam, paling tidak ada tiga pola hubungan: pancosmisme, antroposentrisme dan holisme. Dari ketiga paham tersebut, pola ketiga atau holisme-lah yang direkomendasikan untuk ditumbuhkembangkan. Sedangkan yang pertama dan kedua ditinggalkan jauh-jauh. Lihat dalam Mujiyono Abdillah, Agama Ramah Lingkungan, (Jakarta: Paramadina, 2001), h. 150.

${ }^{3}$ Menurut Shabecoff, kerusakan lingkungan merupakan cerminan krisis intelektual dan spiritual. Kaum intelektual Barat telah melakukan kritik atas filsafat sekuler yang antroposentris yang memisahkan manusia dari kesakralan alam. Para pengkritik tajam di antaranya: John Muir, Rosevelt Arne Naess, Lynn White, Felix Guattari dll. Lihat dalam Philip Shabecoff, A New Name for Peace; International Environmentalism, Sustanaible Development and Democracy, (Hanover: University Press of New England, 1996), h. 221.

${ }^{4}$ Martin Harun, Kata Pengantar; Agama Ramah Lingkungan, (Jakarta: Paramadina, 2001), h. xv

5John A. Grim (ed), Agama, Filsafat dan Lingkungan Hidup, (Yogyakarta: 
Berangkat dari tuduhan-tuduhan di atas, maka ada beberapa pertanyaan yang layak untuk dikaji dan dijawab dalam paper ini. Apakah benar Islam mengajarkan antroposentrisme? Bagaimana konsep ekologi ${ }^{6}$ dalam Islam? Dan bagaimana pandangan Islam tentang hubungan manusia dengan alam dan lingkungan hidup? Pertanyaan-pertanyaan ini sangat mendesak dicari jawabannya untuk kemudian ditemukan pesan-pesan ekologis Islam terkait dengan penanggulangan krisis lingkungan global.

\section{B. Filsafat Antroposentrisme}

Dilihat dari sejarahnya, kelahiran filsafat antroposentrisme berawal dari filsafat pelepasan manusia dari kungkungan Tuhan. Pada abad pertengahan tepatnya, alam pikiran dunia Barat dipenuhi dengan pikiran mitologis. Yakni berakar pada mitologi Yunani, saat itu Barat benar-benar terkungkung di dalam paham keagamaan bahwa seolah-olah Tuhan itu membelenggu manusia.

Paradigma tersebut mulai ditinggalkan dengan munculnya renaissance. Dan, muncul pemikiran bahwa manusia adalah pusat segala sesuatu. Tuhan dan dewa-dewa hanya dianggap sebagai mitos. Muncullah pandangan antroposentrisme muncul sebagai pendobrak pandangan keagamaan mitologi secara revolusioner. Pandangan antroposentrisme atau juga lazim dikenal dengan humanisme beranggapan bahwa kehidupan tidak berpusat pada

Kanisius, 2003), h. 100

${ }^{6}$ Kata ekologi pertama kali diperkenalkan sebagai suatu istilah tersendiri oleh Ernest Hauckel. Kata ini berasal dari istilah Yunani oikos yang bermakna rumah atau tempat tinggal dan logos yang kerap diartikan sebagai ilmu. Secara harfiah, kata ilmu sebagai studi tentang organisme-organisme dalam tempat tinggalnya. Selanjutnya Otto Soemarwoto dengan mengambil kias dari ekonomi, menyebut ekologi sebagai ilmu tentang rumah tangga mahluk hidup. Oxford Advenced Learners Dictionary (1995: 367) menyebutkan bahwa ekologi sebagai suatu studi tentang hubungan antara tumbuhan dan makhluk hidup lainnya antara satu sama lain dan dengan lingkungannya. Lihat dalam Otto Soemarwoto, Ekologi, Lingkungan Hidup dan Pembangunan, (Jakarta: Djambatan, 1997), h. 22. Lebih jauh Capra menyebutkan prinsip-prinsip utama dalam ekologi adalah jaringan, siklus, energi, matahari, kemitraan, keragaman, dan keseimbangan dinamistik. Jaringan dapat ditemukan pada semua skala alam di mana segala sistem saling berkomunikasi dan berbagi sumber daya yang ada tanpa memperhatikan batas-batas mereka yang lebih bersifat sebagai identitas dan bukan sebagai pemisah. Lihat Jonny Purba, Pengelolaan Lingkungan Sosial, (Jakarta: Yayasan Obor Indonesia, 2005), h. 10-12. 
Tuhan, melainkan manusia. Manusialah penguasa realitas, yang menentukan nasibnya sendiri dan kebenaran. Karenanya, Tuhan dan kitab-kitab suci tidak diperlukan lagi. Antroposentrisme sejatinya hadir dengan datangnya rasionalisme yang tidak lagi percaya lagi bahwa hukum alam bersifat mutlak. ${ }^{7}$

Konsep antroposentrisme adalah manusia merdeka dan menjadi pusat dari segala sesuatu. Namun kenyataannya, sekarang telah diturunkan derajatnya menjadi tak lebih sebagai bagian mesin, yakni mesin raksasa teknologi modern. Karena proses inilah, pandangan tentang manusia menjadi tereduksi. Manusia menjadi bagian produksi teknologi modern. Ia hanya menjadi elemen mekanisasi dan elemen otomatisasi teknologi. ${ }^{8}$ Dan paham antrposentrisme saat ini telah merambah ke dunia lingungan hidup. Karena itulah manusia modern menjadi terbelenggu oleh proses teknologi. Manusia teralenasi dari kerja, hasil kerja sesame dan masyarakatnya.

Menurut Resmussen -sebagaimana dikutip oleh Mary Evelyn dan John A. Grim- bahwa akar dari segala permasalahan lingkungan diduga berawal dari filsafat antroposentrisme. ${ }^{9}$ Ia mendefinisikan antroposentrisme sebagai teori etika ligkungan yang memandang pusat alam semesta adalah manusia sehingga kepentingan manusia paling menentukan dalam pengambilan kebijakan berkaitan dengan alam secara langsung maupun tidak. Dalam kalimat Gregory Bateson, sebagaimana dikutip oleh Ramussen, diajukan sebagai berikut :

"....Dan bila Anda menyombongkan diri karena memiliki budi, Anda akan melihat dunia sekitar anda sebagai yang tak berbudi dan oleh karenanya tidak mempunyai hak pertimbangan etis. Lingkungan akan tampak menjadi milik anda untuk dieksploitasi. Unit kelangsungan

${ }^{7}$ Kuntowijoyo, Paradigma Islam Interpretasi Untuk Aksi, (Bandung: Mizan, 1998), h. 156. Selanjutnya Kuntowijoyo memandang bahwa antroposentrisme merupakan cikal bakal dan refleksi budaya Barat. Dan, akhirnya menyebar bak ibarat virus ke seluruh dunia termasuk Indonesia. Lihat uraian lengkapnya pada haman 159-161.

${ }^{8}$ Ibid., h. 162.

${ }^{9}$ Mary Evelyn dan John A. Grim (ed), Agama Filsafat dan Lingkungan Hidup, (Yogyakarta: Kanisius, 2003), h. 217-219. 
hidup anda adalah diri Anda dan sesama atau rekan dengan kekhususan yang sama dengan anda berhadapan dengan lingkungan dari unit-unit social lain rasa-rasa dan binatang dan tumbuhan lain...."10

Antroposentrisme juga diduga kuat berakar kuat dari ajaran agama-agama monotheis, seperti dalam tradisi Yudeo-Kristen tampak pada kitab-kitab kejadian 1: 28

"Allah memberkati mereka (Adam dan Hawa) lalu Allah berfirman kepada mereka: beranak cuculah dan bertambah banyak, dan penuhilah bumi, dan taklukkanlah itu, dan berkuasalah atas ikanikan di laut dan burung-burung di udara dan atas segala binatang yang merayap di bumi”.

Menurut Lynn White, sebagaimana dikutip oleh Martin Harun dalam pengantar buku Agama Ramah Lingkungan, menyebutkan akar permasalahan lingkungan dan alam terdapat pada ajaran Kristen. Lynn mengatakan dalam tulisannya dengan kalimat sebagai berikut:

"Manusia sedikit banyak berbagi dalam transendensi Allah terhadap alam. Kekristenan, dalam kontras mutlak dengan agama kafirkunodan agama-agamaAsia.Takhanya menciptakan dualisme manusia dan alam, tetapi juga menegaskan bahwa telah menjadi kehendak Allah manusia mengeruk (exploit) alam untuk tujuan manusia sendiri". ${ }^{11}$

Lebih lanjut, menurut Mujiyono Abdillah bahwa konstruksi teologi lingkungan yang sudah populer dalam masyarakat disinyalir telah terkontaminasi oleh paham antroposentrisme. Paham antroposentrisme ditandai oleh melonjaknya kesadaran akan rasa percaya diri manusia untuk kuasa atas sumber daya alam dan lingukungan. Kesadaran demikian berkembang pesat karena manusia percaya dirinya sebagai makhluk istimewa dengan berbekal kemampuan rasionalnya. Paham antroposentrisme meyakini bahwa manusia merupakan makhluk yang mempunyai kelebihan dibanding makhluk lainnya. Bahwa sumber daya alam dan

\footnotetext{
${ }^{10}$ Ramussen, Kata Pengantar dalam Mary Evelyn dan John A. Grim (ed), Agama Filsafat dan Lingkungan Hidup, (Yogyakarta: Kanisius, 2003), h. 220.

${ }^{11}$ Martin Harun, Kata Pengantar Agama Ramah Lingkungan, dalam Mujiyono Abdillah, Agama Ramah Lingkungan, (Jakarta: Paramadina, 2001), h. xix-xx.
} 
lingkungan ini diciptakan untuk kepentingan manusia. Karenanya harus dieksploitasi demi kesejahteraan manusia. ${ }^{12}$

Antroposentrisme dalam dimensi kajian Islam diduga bersumber dari prinsip-prinsip dasar Islam yang berkaitan dengan konsep hakikat manusia sebagai makhluk istimewa (super being), manusia sebagai makhluk yang diberi akal (rasional), manusia makhluk yang paling kuasa atas alam (sukhriya') dan konsep khalifah fi al-ard.

Keempat prinsip dasar dan konsep hidup di atas menjadi simpul-simpul teologi yang bias antroposentris. Dengan demikian dapat dipahami bahwa manusia merupakan makhluk terbaik karena dibekali akal. Manusia juga makhluk yang dinamis sedangkan makhluk lainnya statis. Dengan akalnya manusia dapat mengembangkan teknologi untuk menguasai sumber daya alam dan lingkungan bahkan menjelajah angkasa luar. ${ }^{13}$ Filsafat antroposentrisme ini pulalah yang dituding melahirkan filsafat liberalisme dalam pengelolaan alam.

Bahkan racikan konsep maqāṣid as-syari'ah Syațibi diakui sarat dengan filsafat antroposentrisme. Menurut Syațibi, Allah menetapkan syari'at untuk mewujudkan kemaslahatan manusia baik di dunia maupun di akhirat. Pandangan antroposentrisme nampak sekali pada al-ḍrūriyāt al-khamsah: menjaga agama, akal, harta, jiwa dan kehormatan. ${ }^{14}$ Semua dimensi yang lima tersebut hanya human oriented. Sementara kajian maslahat lingkungan belum tersentuh olehnya. Implikasinya, dalam segala aktivitasnya selalu berorientasi pada kemaslahatan manusia.

\section{Ayat-ayat Antroposentris}

Terdapat ayat-ayat al-Qur'an yang disinyalir mengandung nilai dan paham antroposentrisme. Pertama, adalah konsep manusia sebagai makhluk yang paling istimewa terdapat dalam surat al- Tin ayat 4:

${ }^{12}$ Mujiyono Abdillah, Fikih Lingkungan; Panduan Spiritual Hidup Berwawasan Lingkungan, (Yogyakarta: UPP AMP YKPN, 2005), h. 34.

${ }_{13}$ Mujiyono Abdillah, Agama Ramah Lingkungan, (Jakarta: Paramadina, 2001), h. 11-13.

${ }^{14}$ as-Syațibi, al-Muwafaqāt fi Ușul al-Syarīah, ed. Khudari Husein, Jilid II, (Beirut: Dār al-Fikr, 1341), h. 3 dst. 


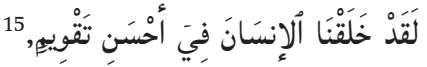

ada juga terdapat dalam surat al-Isrā' ayat 70:

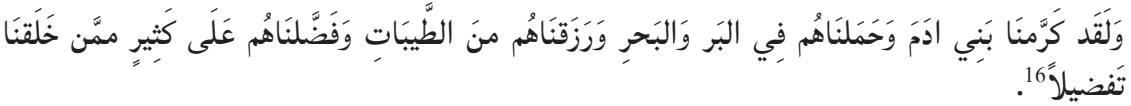

Surat al-Infițār ayat 7-8:

Surat al-Tagābun ayat 3:

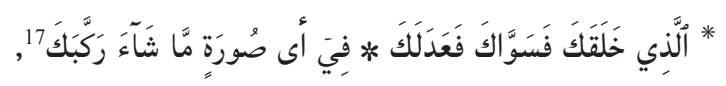

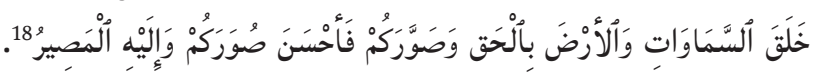

Kedua, Ayat-ayat yang menggambarkan manusia sebagai makhluk berakal. Terdapat dalam surat al-Baqarah ayat 75:

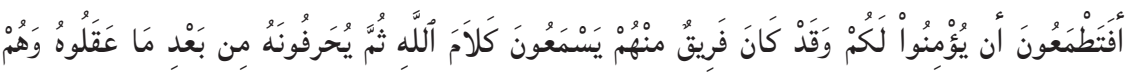

Surat al-Nahl 78:

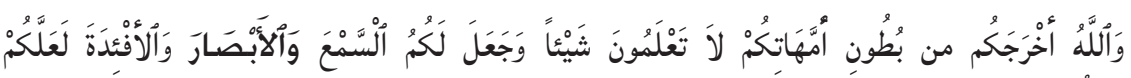

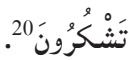

Ada juga dalam surat al-Rum ayat 7:

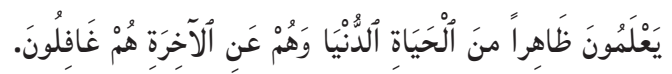

Dan masih banyak ayat lainnya yang berbicara bahwa

\footnotetext{
${ }^{15}$ Artinya: "sesungguhnya Kami telah menciptakan manusia dalam bentuk yang sebaik-baiknya"

${ }^{16}$ Artinya: "Dan sesungguhnya telah Kami muliakan anak-anak Adam, Kami angkut mereka di daratan dan di lautan, Kami beri mereka rezki dari yang baik-baik dan Kami lebihkan mereka dengan kelebihan yang sempurna atas kebanyakan makhluk yang telah Kami ciptakan".

${ }^{17}$ Artinya: "Yang telah menciptakan kamu lalu menyempurnakan kejadianmu dan menjadikan (susunan tubuh) mu seimbang. Dalam bentuk apa saja yang Dia kehendaki, Dia menyusun tubuh-mu.

${ }^{18}$ Artinya: "Dia menciptakan langit dan bumi dengan (tujuan) yang benar, Dia membentuk rupamu dan dibaguskan-Nya rupamu itu, dan hanya kepada-Nya lah kembali (mu).

${ }^{19}$ Artinya: "apakah kamu masih mengharap mereka akan percaya kepadamu, padah segolongan dari mereka mendengar firman allah lalu mereka mengubahnya setelah mereka memahaminya, sedang mereka mengetahui.

${ }^{20}$ Artinya: "Dan Allah mengeluarkan kamu dari perut ibumu dalam keadaan tidak mengetahui sesuatupun, dan Dia memberi kamu pendengaran, penglihatan dan hati agar kamu bersyukur".
} 
manusia makhluk berakal. Di antaranya terdapat dalam QS. AlAnfāl: 21, QS. Al-Hajj: 46, QS. Al-Ra'd: 2, QS. Hūd: 123. Dengan demikian, banyak yang beranggapan bahwa makhluk lainnya lebih rendah dari manusia karena tidak berakal.

Ketiga, ayat-ayat yang menggambarkan manusia sebagai paling kuasa atas sumber daya alam dan lingkungan. Sebab alam semesta ini diciptaka hanya untuk manusia. Terdapat dalam surat al-Baqarah: 22:

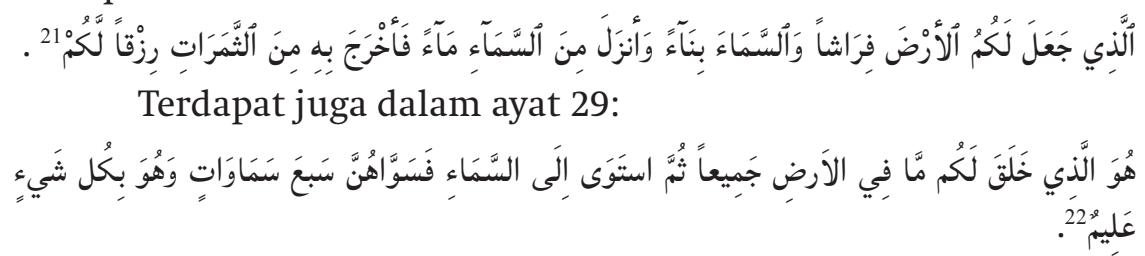

Terdapat juga dalam surat al-Jatsiyah: 13:

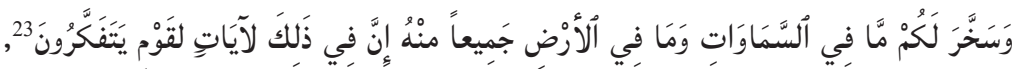

Terdapat juga dalam surat Luqman: 20

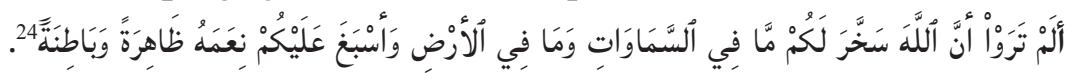

Keempat adalah ayat-ayat tentang kedudukan manusia sebagai manifestasi wakil Allah di bumi. Terdapat dalam surat alBaqarah: 30:

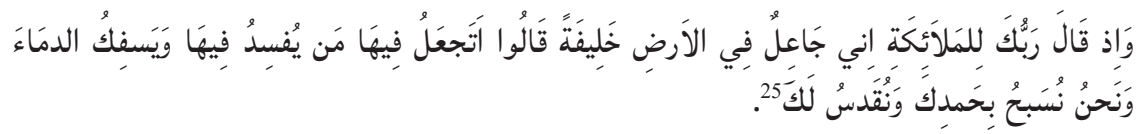

${ }^{21}$ Artinya: "Dialah yang menjadikan bumi sebagai hamparan bagimu dan langit sebagai atap, dan Dia menurunkan air hujan dari langit, lalu menghasilkan dengan hujan itu segala buah-buahan sebagai rezki untukmu".

${ }^{22}$ Artinya: "Dialah Allah, yang menjadikan segala yang ada di bumi untuk kamu dan Dia berkehendak (menciptakan) langit, lalu dijadikan-Nya tujuh langit, dan Dia Maha Mengetahui segala sesuatu”.

${ }^{23}$ Artinya: "dan Dia menundukkan untukmu apa yang ada di langit dan apa yang ada di bumi semuanya, sebagai rahmat dari-Nya. Sesungguhnya pada yang demikian benarbenar terdapat tanda-tanda kekuasaan Allah bagi kaum yang berfikir".

${ }^{24}$ Artinya: "Tidakkah kamu perhatikan sesungguhnya Allah telah menundukkan untuk (kepentingan)mu apa yang di langit dan apa yang di bumi dan menyempurnakan untukmu ni'mat-Nya lahir dan batin".

${ }^{25}$ Artinya: "Ingatlah ketika Tuhanmu berfirman kepada para malaikat: "sesungguhnya Aku hendak menjadikan seorang "khifah" di muka bumi. Mereka berkata: mengapa Engkau hendak menjadikan khifah di bumi itu orang yang akan membuat kerusakan padanya dan menumpahkan darah, padah kami senantiasa bertasbih dengan 
Juga terdapat dalam surat al-An'am: 165

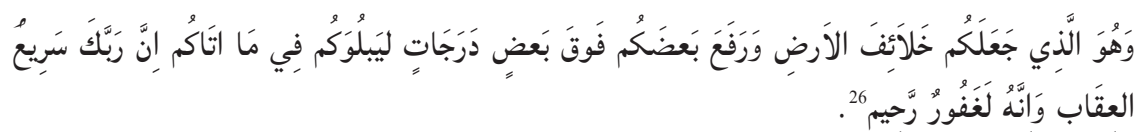

Dalam QS. Shad: 26:

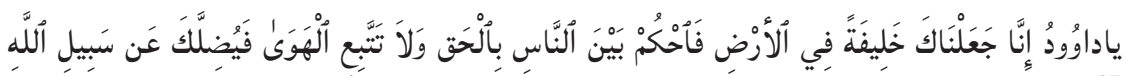

Keempat dasar keagamaan di atas kemudian diduga melebur menjadi satu dalam bingkai teologi lingkungan yang "terkesan" antroposentris. Gejala-gejala demikian nampak ketika dijumpai dalam kehidupan nyata akan perilaku masyarakat yang tidak mencerminkan perilaku ekologis. Mulai dari eksplorasi alam tanpa batas, boros energi, pencemaran dan sebagainya. Keyakinan antroposentris inilah yang sudah saatnya ditafsir ulang dan dibongkar dengan ayat-ayat ekologis. Berikut ini keempat prinsip dasar tersebut akan dibedah dengan pendekatan tanāsubu alàāt. Harapannya cara penafsiran atomistik dapat dihindari agar ditemukan maqāṣid Tuhan terkait pesan-pesan ekologis.

Pertama, terkait dengan konsep keistimewaan manusia sebagai makhluk yang paling sempurna. Konteks kesempurnaan dalam ayat-ayat di atas hanya dipahami sebatas kesempurnaan fisik. Dan, jaminan kesempurnaan manusia terwujud ketika dimensi spiritual dan amaliahnya terpenuhi. Sebagaimana dijelaskan dalam tafsir al-Qurthubi yang menjelaskan makna sebaik-baiknya bentuk ditafsiri dengan:

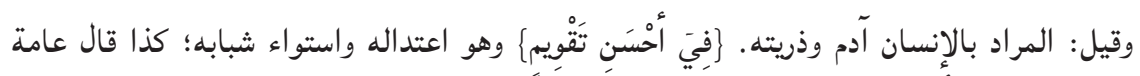

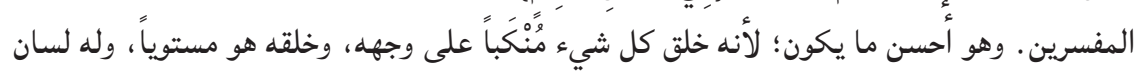

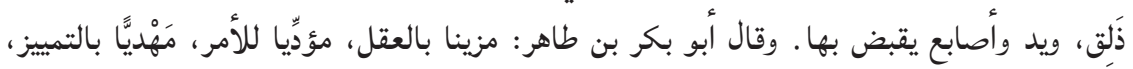

memuji dan mensucikan Engkau"...

${ }^{26}$ Artinya: "dan Dialah yang menjadikan kamu penguasa-penguasa di bumi dan Dia meninggikan sebagian kamu atas sebagaian yang lain beberapa derajat, untuk mengujimu tentang apa-yang diberikan-Nya kepadamu.Sesungguhnya Tuhanmu amat cepat siksaan-Nya dan sesungguhnya Dia Maha Pengampun lagi Maha Penyayang.

${ }^{27}$ Artinya: "wahai Dawud, sesungguhnya Kami menjadikan kamu penguasa di muka bumi, maka berilah keputusan (perkara) di antara manusia dengan adil dan janganlah kamu mengikuti hawa nafsu, karena ia akan menyesatkan kamu dari jalan Allah". 


$$
\text { مديد القامة؛ يتناول مأكوله بيده }
$$

Dengan demikian maka dimensi non-fisik justru lebih penting yaitu aspek keimanan (shaleh secara individual) dan aspek amal shalih (shaleh secara sosial). Tegasnya, manusia berpotensi menjadi lebih rendah ketika dua dimensi tersebut tidak tertampilkan dalam diri manusia. Sebagaimana dinyatakan dalam Surat al-Nahl ayat 97:

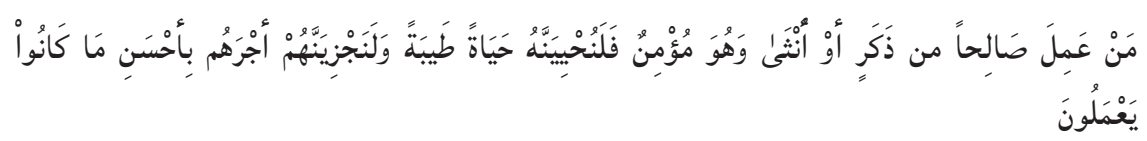

Ketika menafsiri ayat di atas Ibnu Kașir menjelaskan dengan kalimat:

هذا وعد من الله تعالى لمن عمل صالحاً وهو العمل المتابع لكتاب الله تعالى وسنة نبيه صلى الله

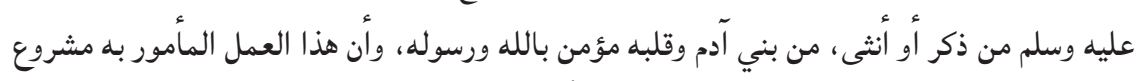

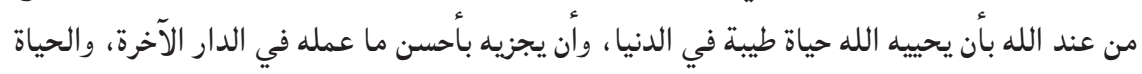
الطيبة تشمل وجوه الر احة من أي جهة كانت. 29

Ayat di atas menegaskan ada tiga variabel dalam ayat tersebut terkait dengan kehidupan yang berkualitas. Yaitu: berbuat baik ('amal șālih), religiusitas (al-imān) dan kehidupan yang berkualitas (hayātan tayyibatan). Ketiga variabel tersebut merupakan mata rantai yang tidak bisa dipisahkan satu sama lain. Maka kehidupan berkualitas baik di dunia maupun di akhirat hanya diperuntukkan bagi orang yang beriman dan beramal saleh. al-Qațtan memaknai amal shalih yaitu amal baik termasuk urusan-urusan kemasyarakat termasuk lingkungan. Dengan demikian dapat dikatakan bahwa kesempurnaan fisik manusia ditentukan kesempurnaan amal shaleh.

Dalam hubungannya dengan lingkungan alam, kesempurnaan manusia juga tidak menjadi variabel dominan dalam alQur'an. Manusia sejatinya hanya bagian kecil dari lingkungan alam

${ }^{28} \mathrm{Abu}$ Abdillah Muhammad Ibn Ahmad al-Anșāri al-Qurthubi, Jami' li Ahkām al-Qur'an, Jilid 8, (Beirut: Dār al-Fikr al-'Ilmiyah, 1992), h. 113.

${ }^{29}$ Lihat: Ibnu Kasìr, Tafsìr al-Qur'an al-Adzīm, Jilid IV, (Beirut: Dār al-Fikr, 1992), h 516. 
ini. Keterbatasan kesempurnaan manusia ditegaskan Allah dalam surat al-Isra' ayat 37-38:

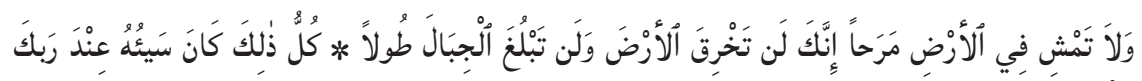

Dan juga terdapat dalam surat al-'Alaq 6-7:

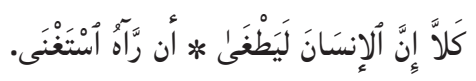

Dua ayat di atas mengisyaratkan kepada kita akan keterbatasan dan kekurangsempurnaan manusia terhadap alam ini. Dan, terkadang manusia juga kelewatan batas dalam mengelola alam ini. Dalam menafsiri ayat ini al-Qurthubi mengatakan:

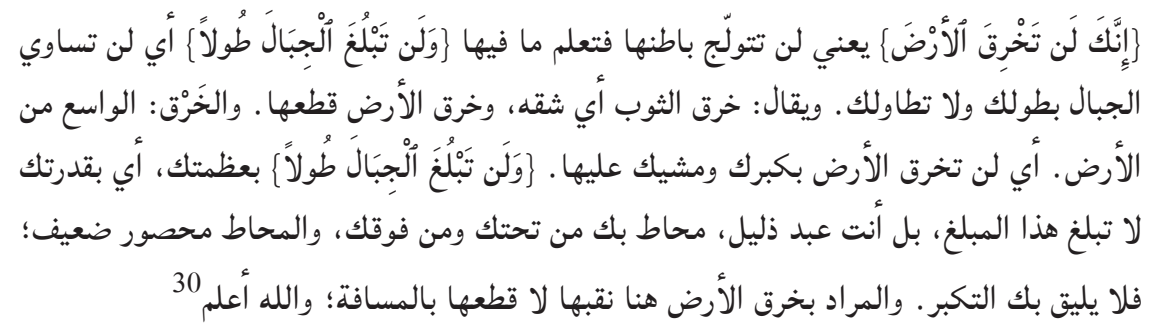

Kutipan al-Qurthubi di atas jelas memposisikan kelemahan manusia di hadapan alam. Bumi dan gunung adalah bagian dari ekosistem yang tidak boleh dieksploitasi sesuai kemauan dan kesenangan manusia. Sebab dieksplorasi sekuat apapun, keduanya tidak akan -dengan penggunaan huruf lan- mampu ditaklukkan oleh manusia.

Kedua, terkait dengan ayat-ayat yang mengedepankan keistimewaan akal manusia. Ayat-ayat di atas juga dituduh sebagai basis antroposentrisme dalam Islam. Benar bahwa akal adalah anugerah luar biasa yang membedakannya dengan makhluk lain. Dengan akal manusia diharapkan mampu mengelola alam dan lingkungan dengan baik. Karena sejatinya penciptaan manusia bermotif pemakmur atau pembangun bumi dan bukan untuk sebaliknya, merusak bumi ini. Hal ini ditegaskan Allah dalam surat al-Hūd ayat 61:

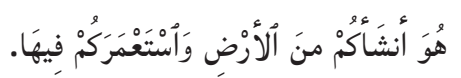

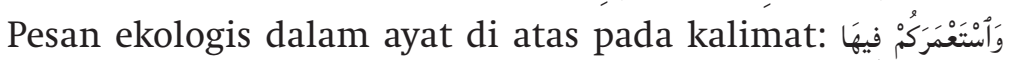
yang berarti memerintahkan manusia untuk memakmurkán bumi.

${ }^{30}$ al-Qurthubi, Jami' li Ahkam..., juz 5, h. 260. 
Dalam hal ini Ibnu Katsir menafsiri ayat di atas dengan pemahaman dan makna manusia untuk melaksanakan pembangunan dan mengelola bumi. ${ }^{31}$

Lebih dari itu, menurut Harun Nasution akal manusia adalah pelengkap wahyu dan panca indera bagi manusia dalam memahami alam. Akal adalah pembantu wahyu Allah dalam memahami alam semesta dan lingkungan. ${ }^{32}$ al-Qur'an sendiri tidak menafikan peran pengamatan dan penalaran akal dalam memahami alam ini. ${ }^{33}$ Namun demikian, dalam banyak variannya al-Qur'an juga mencela manusia ketika tidak mampu menggunakan akalnya dengan baik. Penggunaan akal dengan baik dalam konteks pemeliharaan lingkungan dan alam ini adalah mengetahui yang baik dan buruk dalam mengelola alam ini. Namun jika akal ini tidak digunakan sebagaimana mestinya maka posisi manusia sama bakan lebih rendan (hina) dari makhluk yang bernama binatang. ${ }^{34}$

Al-Qur'anjugabanyakmenyuruh kerja akal untukmemahami kerusakan lingkungan dan alam. Refleksi akal sangat ditekankan agar pembangunan di bumi ini berjalan secara berkelanjutan. Hal ini dapat dilihat dalam surat al-Rum ayat 9:

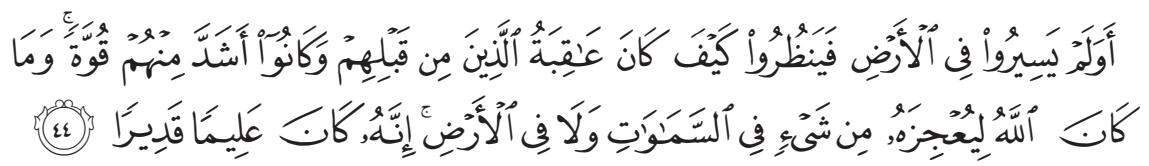

Terdapat juga dalam surat al-Jäsiyah ayat 13:

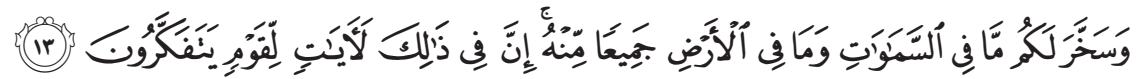

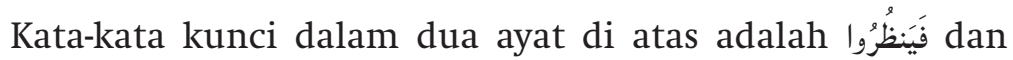
يَنَكُكُونَ yang menunjukkan urgensi akal manusia untuk memelihara alam dan menghindari dari kerusakan di bumi ini. Ayat di atas juga menegaskan bahwa manusia sebagai spesies yang berakal dan beragama wajib hukumnya memelihara lingkungan. Sebab

${ }^{31}$ Ibnu Kàīr, Tafsir al-Qur'an al-Adzim, Jilid II, (Beirut: Dār al-Fikr, 1992, h. 548.

${ }^{32}$ Harun Nasution, Akal dan Wahyu dalam Islam, (Jakarta: UI Press, 1998), h. 23.

${ }^{33}$ Lihat QS an-Nahl: 78, aż-Żāriyāt: 49, ar-Rūm: 7, al-Anfāl: 21, al-Hajj: 46, ar-Ra'du: 2, al-Hāqqah ayat 38-39 dan Hud ayat 123.

${ }^{34}$ Lihat QS al-'Arāf : 179 dan surat al-Furqān: 44. 
pada kenyataannya manusia meruapakan makhluk lingkungan. Sehingga hubungan manusia dengan makhluk lain bersifat simbiosis mutualisme. Manusia membutuhkan lingkungan (spesies lain) dan sebaliknya, lingkungan membutuhkan manusia. Dengan demikian dapat disimpulkan bahwa sejatinya Islam adalah agama yang sangat peduli dengan persoalan pemeliharaan dan pelestarian lingkungan.

Ketiga, ayat-ayat berkaitan dengan konsep "sukhriya" bahwa Allah menciptakan alam dan bumi hanya untuk manusia. Munculnya mainstream demikian karena memahami al-Qur'an secara atomistik dan parsial. Jika dilacak lebih jauh, Allah menciptakan planet bumi dan lingkungan ini tidak hanya diperuntukkan bagi manusia. Melainkan seluruh makhluk Allah. Sebagaimana termaktub dalam surat al-Rahman ayat 10 :

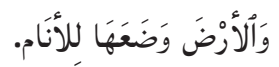

Kata الأنام dalam ayat ini ditafsiri oleh al-Syinqithi dengan al-khalqu yaitu semua ciptaan Allah (seluruh spesies), sedangkan كل ما دبّ على وجه الأرض، وهذا عام menurut al-Qurțubi makna al-anam adalah yaitu merayap yang hidup di atas bumi ini secara umum.

Telaah lebih dalam lagi, pada ayat-ayat sukhriya adalah dalam kata-kata bahwa huruf lām di sini bermakna lām li al-tanfi' yaitu hak manusia untuk memanfaatkan bumi ini. Dan, huruf lām tidak atau bukan bermakna lam li al-tamlik atau hak memiliki bumi. Sebab pada hakikatnya yang memiliki bumi dan alam semesta ini hanya Allah bukan manusia.

Manusia sebagai sesama ciptaan Allah merupakan bagian yang tidak terpisahkan dari jaringan besar yang bersifat kompleks dari sistem ekologi alam. Manusia bernafas dengan menghirup oksigen dan mengeluarkan karbondioksida sehingga turut menjadi bagian dalam siklus oksigen di alam manusia makan dan membuang kotoran sisa hasil metabolismenya ke alam, sehingga turut menjadi bagian dari aliran energi di alam yang sumber utama dari energi matahari. Sebagaimana ditegaskan dalam surat al-Ra'du ayat 4:

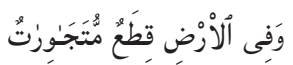

ayat ini ditafsiri oleh Ibnu Katsir dengan ungkapan 
أي أراض يجاور بعضها بعضاً، مع أن هذه طيبة تنبت ما ينفع الناس وهذه سبخة مالحة لا تنبت شيئًا.

Dalam bahasa yang lebih lugas, ayat di atas dapat dipahami dan dikatakan bahwa dalam lingkungan hidup terdapat ekosistem sebagai penyangga kehidupan.

Keempat, terkait antroposentrisme dalam ayat-ayat manusia sebagai khalifah di bumi. Secara bahasa khalifah berarti orang yang datang (ada) belakangan yang menggantikan orang sebelumnya. Dalam hal ini Ibnu Ishaq -sebagaimana dijelaskan at-Thabari menafsiri khailfah dengan ungkapan:

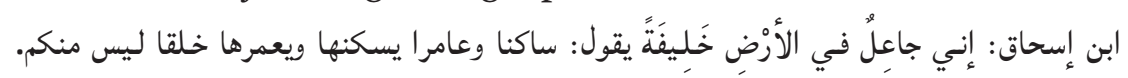

Yakni berperan sebagai penduduk, pembangun bumi ini menggantikan peran iblis yang sebelumnya telah menempati bumi dan dibinasakan malaikat dan digantikan dengan Adam. ${ }^{36}$ Dengan demikian jelas manusia sebagai khalifah bukanlah penguasa bumi, melainkan penerus yang secara fungsional untuk memelihara dan memakmurkan bumi ini.

Machasin dalam Aminah dkk menjelaskan secara ringkas khalifah adalah memegang amanat atau mandat. ${ }^{37}$ Lebih lanjut dijelaskan kekhalifahan berarti manusia menjadi memegang mandat Tuhan untuk menyelenggarakan kehidupan bertanggung jawab. Hakikat khalifah menurut al-Maududi ialah manusia bukan pemilik, apalagi penguasa, segala yang di atas bumi, namun hanya sebagai wakil dari sang pemilik sejati yaitu Allah. ${ }^{38}$

Sebagai khatifah, manusia diberi kelebihan dibandingkan dengan ciptaan yang lain. Kelebihan utamanya adalah adanya kemampuan manusia untuk berfikir atau kepemilikan akal

\section{${ }^{35}$ Lihat Ibnu Kasirr, Tafsìr..., Juz 6, h. 369.}

${ }^{36}$ Dalam kitab al-Tabari diurai detail tentang pengutusan Adam di bumi dalam menggantikan posisi Iblis yang merusak bumi dan menumpahkan darahnya. Jadi khifah dalam konteks ini dimaknai Adam adalah yang menggantikan (khalifah) datang berikutnya setelah iblis binasa. Lihat dalam tafsir karya Abu Ja'far al-Ṭabari, Jamĭ al-Bayān fi Ta'wīl al-Qur'ān, jilid 1, (t.t: Muassasah al-Risālah, 2000), h. 449-450.

${ }^{37}$ Wiwin Siti Aminah, Haryandi, dan Alfred Benedictus (ed). Sejarah Teologi, dan Etika Agama-agama, (Yogyakarta: Dian Interfidle, 2005), h. 164-165.

${ }^{38} \mathrm{Abu}$ 'Alā al-Mawdudi, Khilāfah dan Kerajaan; Evaluasi Kritis atas Sejarah Pemerintahan Islam, (Bandung: Mizan,1994), h. 64. 
yang sempurna dibandingkan makhluk alinnya. Allah swt telah mengajarkan pada Adam semua nama-nama sesuatu yang tidak diketahui oleh para malaikat, sehingga malaikat pun bersedia bersujud kepada manusia, atas perintah Allah swt, kecuali Iblis yang ingkar terhadap perintah-Nya. ${ }^{39}$

Kelebihan kedua adalah keberadaan kehendak bebas pada manusia. Dalam berbagai aliran teologi Islam konsep kebebasan kehendak ini telah menjadi pertentangan sengit antara kaum Qadariyah dengan kaum Jabariyah, di mana yang pertama mengakui adanya kebebasan kehendak manusia sedangkan yang kedua menafikannya. Meskipun begitu, Asy'ariyah berusaha mendamaikan dan mengatakan bahwa manusia mempunyai kebebasan walaupun itu hanyalah suatu hiasan karena sebenarnya segalanya dari Tuhan. ${ }^{40}$ Bagaimanapun juga, al-Qur'an telah menegaskan manusia diberi kebebasan untuk beriman atau kafir, dengan masing-masing pilihan mempunyai konsekuensi tersendiri. ${ }^{41}$ Fazlur Rahman menambahkan, berbeda dengan alam semesta yang secara otomatis mentaati Allah swt, manusia dapat memilih untuk taat atau ingkar kepada Allah swt. ${ }^{42}$

Ibnu Arabi -sebagaimana disitir Chittick- berangkat dari konsep yang sering disebut dengan konsep waḥdat al-wujūd, menafsirkan kalimat Allah SWT mengajarkan Adam semua namanama dengan pengertian bahwa manusia adalah manifestasi paling sempurna dari semua atribut-atribut Allah SWT. Setiap manusia secara individual dapat merefleksikan diri dari setiap atribut keTuhan-an. Ciptaan lainnya di alam semesta sendiri hanya mampu mewujudkan setiap atribut tertentu saja. Karena itulah dalam alam semua ciptaan mempunyai keadaan yang bertingkat-tingkat sesuai dengan perwujudan atribut yang dipunyainya. Manusia adalah tingkatan tertinggi karena kemampuannya tersebut. Manusia walaupun dalam bentuk akhirnya stabil namun labil dalam batinnya sehingga manusia dapat mencapai berbagai tingkatan sepiritual.

${ }^{39}$ QS. al-Baqarah (2) : 31-34.

${ }^{40}$ Harun Nasution, Teologi Islam: Aliran-aliran Sejarah Analisa Perbandingan, (Jakarta: Penerbit Universitas Indonesia, 2000), h. 103-117.

${ }^{41}$ Lihat QS. Fātiir (35): 39.

${ }^{42}$ Fazlur Rahman, Islam, Terj. Ahsin Muhammad, (Bandung: Pustaka, 1996), h. 95 . 
Manusia dapat lebih mulia dari malaikat, namun juga dapat jatuh ke tingkatan yang lebih rendah dari binatang ternak. ${ }^{43}$

Dalam pandangan Ibnu Arabi, dunia manusia dan mikrokosmos adalah serupa. Ibnu Arabi sering menyebutkan denga istilah dunia kecil (mikrokosmos) bagi manusia dan dunia besar (makrokosmos) bagi alam semesta. Istilah lain juga dipakaianya yaitu manusia kecil (mikroantropus) dan manusia besar (macroantropus). Mikrokosmos adalah sebuah kesadaran sedangkan makrokosmos hanyalah suatu intstrumen pasif dalam kuasa Tuhan. Dalam ilustrasi yang sangat indah, manusia bagi alam semesta ini adalah ibarat ruh bagi jasad manusia. ${ }^{44}$ Dalam al-Futtuhat al-Makkiyah, sebagaimana dikutip Chittick, Ibnu Arabi menjelaskan dengan nada jelas :

"Bedakan dirimu sendiri dari kosmos dan bedakan kosmos dari dirimu. Bedakan yang lahir dan yang batin, dan yang batin dari yang lahir. Bagi kosmos kalian adalah ruh kosmos, dan kosmos adalah bentuk lahiriyah kalian. Bentuk ini yang tidak mempunyai makna apa pun tanpa ruh. Oleh sebab itu, kosmos tidak memiliki arti tanpa kalian". ${ }^{45}$

Sepenggal kalimat di atas menegaskan bahwa antara manusia dan alam adalah satu kesatuan yang tidak bisa dipisahkan. Keduanya dilukiskan ibarat tubuh dan ruh yang saling melengkapi. Artinya jika ruh dalam tubuh manusia hilang maka rusak tubuh tersebut yang pada akhirnya akan rusak dan hancur pula jasad tersebut.

Analisa-analisa di atas akhirnya semakin meneguhkan bahwa sejatinya atroposentrisme tidak ditemukan apalagi diajarkan dalam Islam. Dalam ekologi Islam, justru menempatkan manusia secara proporsional. Meskipun manusia mempunyai kelebihan dibanding makhluk lain, keberadaannya masih menjadi bagian dari lingkungan dan bukan berada di luar ekosistem. Bahwa lingkungan alam ini diciptakan manusia bukanlah pandangan keliru. Namun manusia bukanlah pemilik alam ini. Dengan demikian manusia tidak boleh mengeksploitasi alam dengan seenaknya sendiri. Semua harus tetap mengacu pada kelestarian dan hak asasi lingkungan

${ }^{43}$ William C. Chittick, Dunia Imajinal Ibnu'Arabi; Kreativitas Imajinasi dan Persoalan Diversitas Agama, (Surabaya: Risalah Gusti, 2001), h. 56-57.

${ }^{44}$ Ibid., h. 60.

${ }^{45}$ Ibid., h. 61. 
dengan tetap berbasis pada penalaran rasional ekologis manusia sebagai makhluk yang berakal.

Islam melarang keras paham antroposentrisme dalam pengelolaan lingkungan. Sebab antroposentrisme sejatinya identik dengan mental orang-orang paganis. Dan benih-benih antroposentrisme justru lahir dari orang-orang paganistis. Sebab dalam paham ini manusia meyakini hanya manusia lah yang paling berkuasa. Tidak ada kekuatan kecuali kekuatan manusia. Akibatnya timbul sikap manusia yang meremehkan dan merendahkan makhluk lain. Sikap dan mental paganistis yang antroposentris telah dikecam oleh al-Qur'an dalam surat al-Baqarah ayat 6-12:

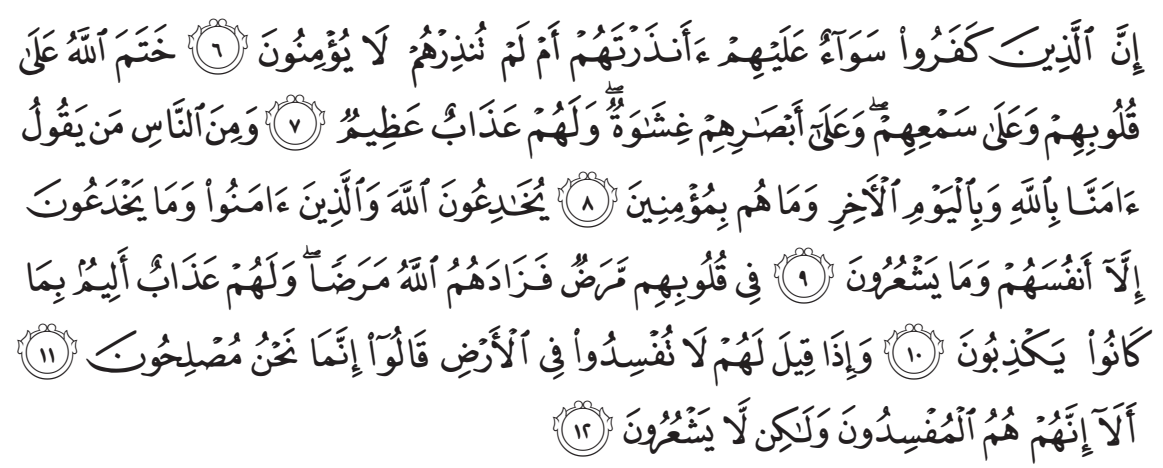

Ayat ini mengisyaratkan korelasi kuat antara paganis, antroposentis dan kerusakan lingkungan. Indikator orang-orang pagan adalah keras kepala, keras hati, penuh kamuflase dan angkuh dalam pengelolaan lingkungan. Mereka selalu berdalih membangun bumi, padahal sejatinya mereka merusak. Dengan demikian, dapat dikatakan bahwa kerusakan alam yang parah saat ini akarnya bukan pada antroposentrisme Islam (theogenik), namun pada pola tingkah manusia yang kelewat batas (antrogenik). ${ }^{46}$

\section{Ekologi Perspektif Islam}

Menurut Chapman, dewasa ini semua agama: Islam, Kristen, Yahudi, Hindhu, Budha, Tao dan lain-lainnya, sejatinya telah

${ }^{46}$ Lihat lebih detail pada ayat-ayat lainnya yang menggambarkan bahwa kerusakan lingkungan bumi ini karena ulah tangan manusia. Banyak ayat yang menjelaskan tema-tema kerusakan lingkungan karena dominasi manusia atas ala mini. Lihat QS. ar-Rūm (30): 9, 41, QS. an-Naḥl (16): 33, al-Ankabūt (29): 31 dan QS. Hūd (11): 117. 
menumbuhkan kesadaran akan kearifan terhadap lingkungan hidup. ${ }^{47}$ Dari sisi ajaran Islam misalnya, kita mengenal kearifan lingkungan dari konsep-konsep semisal tauhìd, ihsān, syukr, khaTifah Allāh fi-ard, amānah, akhirat, dan raḥmatan li al-'àlamin.

Tauhid merupakan pilar dan pijakan seluruh aktivitas manusia terhadap Tuhan dan alam. Tauhìi dengan demikian mampu memancarkan peran khalifah Alläh fi-arḍ yang secara bertanggungjawab mengelola dan memanfaatkan sumber daya alam dengan baik dan seimbang. Eksplorasi alam ini tentunya sebagai manifestasi rasa syukur dan wujud belas kasih atau rahmatan li al-ālamin kepada alam lingkungan. Operasi dan implementasi tauhìd, syukur dan khalifah Allāh dan sifat ramah lingkungan semuanya merupakan manifestasi sifat amänah dan sikap ihsan. Dengan demikian, perbuatan-perbuatan manusia akan dimintakan pertanggungjawabannya di akhirat nanti (ini konsep eschathology). ${ }^{48}$ Konsep-konsep di atas merupakan mata rantai aplikatif dan sebagi jawaban bahwa Islam sejatinya peduli terhadap lingkungan.

Lebih jauh, dua pemikir muslim modern, Sayyed Hossein Nasr dan Yusufal-Qaraḍawi juga mengurai konsep iḥsān sebagai salah satu pilar Islam terhadap pemeliharaan lingkungan. Kata Qaraḍawi, ihsān dapat dimaknai dalam dua pengertian: pertama, melindungi dan menjaga dengan sempurna. Kedua, bermakna memperhatikan, menyayangi, merawat dan menghormati. ${ }^{49}$ Pandangan Qaraḍawi menegaskan bahwa Islam peduli dengan lingkungan. Meski belum nampak teknik operasional bentuk konservasi lingkungan.

Sayyed Hossein Nașr juga menilai bahwa konsep ihsan dalam Islam. Menurut Nașr, ihsān melambangkan the beauty of human soul (keindahan jiwa manusia). Lebih detail Nasr menjelaskan: "The person who has realized ihsan is fully aware of the centrality of the qualities of compassion and love, peace and beauty in the Islamic spiritual universe and

${ }^{47}$ Audrey R. Peterson Chapman, et. Al. (eds), Consumption, Population and Sustainability: Perspectives from Science and Religion (Washington DC: Island Press, 2000) h. 1

${ }^{48}$ Mudhofir Abdullah, Jurnal Ijtihad, dalam "Globalisasi dan krisis ekologi: Upaya konservasi dalam Perspektif Fikih Lingkungan, (Salatiga: STAIN Salatiga, 2010), vol. 10, Nomor 2, h. 160.

${ }^{49}$ Yusuf al-Qaraḍawi, Islam Agama Ramah Lingkungan, terj. Abdullah Hakam Syah dkk., (Jakarta: Pustaka al-Kautsar, 2002), h. 184 
is able to see written on the Divine Throne. (orang yang sadar akan ihsan sepenuhnya sadar akan makna penting sifat-sifat belas kasih dan cinta kasih, perdamaian dan keindahan dalam semesta spiritual Islam dan ia dapat melihat dengan mata batin akan ayat-ayat yang tertulis di dalam Tahta Ilahi). Nașr juga mengutip hadis Qudsi yang berbunyi: inna rahmati taglibu gadabi (sesungguhnya rahmat-Ku mengalahkan siksa-Ku)..$^{50}$ Pandangan al-Qaraḍawi dan Nașr di atas menegaskan bahwa antroposentrisme dalam Islam sejatinya tidak ada dan tidak diajarkan.

Selanjutnya, embrio-embrio gagasan ekologis-teologis di atas, meskipun bersifat normatif, menurut hemat penulis, laik dan saatnya untuk dikembangkan dalam rangka menciptakan peradaban Islam yang ramah lingkungan. Dengan basis ekologis-normatif diharapkan lahir para intelektual dan manusia yang berwawasan lingkungan hidup. Fakta sejarah menampilkan, dengan basis syariah normatif mampu melahirkan manusia-manusia berkualitas pada abad pertengahan. Inilah yang oleh Nașr Ḥāmid Abū Zaid diistilahkan dengan hadarāt an-naș (peradaban teks). Peradaban teks meskipun bernuansa apologis dan romantisisme sejarah, telah digunakan karakter bangsa Arab yang melalui 'peradaban teks' yang hanya berbasis pada dimensi deduktif, platonik dan atomistik, faktanya mampu berkembang. ${ }^{51}$ Berbeda dengan peradaban Barat yang berdimensi induktif, empirisme dan penelitian-penelitian ilmiah.

Namun demikian, peran teks-teks syari'ah dalam konservasi lingkungan tidak dapat dinafikan begitu saja. Ia berperan pada penguatan basis-basis intelektual dan spiritual. Sebab, menurut penulis konservasi lingkungan dan alam yang terlanjur rusak ini, tidak cukup diselesaikan dengan aktivitas-aktivitas fisik dan teknologi an sich. Melainkan dimensi yang tidak kalah penting adalah penguatan dimensi non-fisik yaitu spiritual dan intelektual yang berwawasan lingkungan hidup. Dengan demikian dekonstruksi tafsir ini diharapkan mampu memperkuat basis-basis tersebut.

\footnotetext{
${ }^{50}$ Sayyed Hossein Nașr, The Heart of Islam: Enduring Values for Humanity, (New York: Harper Collins Publisher, Inc., 2002), h. 236.

${ }^{51}$ Nașr Ḥāmid Abū Zaid, Mafhūm an-Naṣ; Dirāsat fi 'Ulūm al-Qur'ān, (Beirut: alMarkaz al-Śaqafi al-'Arabỉ, 1994), h. 4
} 


\section{E. Kesimpulan}

Dari uraian dan analisis di atas dapat diambil kesimpulankesimpulan bahwa antroposentrisme sejatinya lahir bukan dari agama Islam. Pandangan antroposentrisme muncul disebabkan metode penafsiran yang parsial dan atomistik. Islam memandang manusia dengan lingkungan alam bersifat simbiosa mutual dan manusia secara fungsional merupakan makhluk pembangun (khaTifah) yang amanah dan ber-ihsān. Konsep pembangunan Islam bersifat menyeluruh dan integral dengan tetap mengedepankan aspek kelestarian lingkungan. Dengan demikian dapat dikatakan bahwa konsep ekoteologi Islam adalah membangun bumi dan manusia dengan prinsip keseimbangan.[]

\section{Daftar Pustaka}

Aminah, Siti, Wiwin, Haryandi, dan Alfred Benedictus (ed). Sejarah Teologi, dan Etika Agama-agama, Yogyakarta: Dian Interfidei, 2005.

Chapman, Audrey, R. Peterson, (eds), Consumption, Population and Sustainability: Perspectives from Science and Religion, Washington DC: Island Press, 2000.

Chittick, William C., Dunia Imajinal Ibnu'Arabi: Kreativitas Imajinasi dan Persoalan Diversitas Agama, Surabaya: Risalah Gusti, 2001.

Departemen Agama, al-Qur'an dan Terjemahnya, Jakarta: PT. Bumi Restu, 1976.

Evelyn, Mary \& Grim, John A. (ed), Agama Filsafat dan Lingkungan Hidup, Yogyakarta: Kanisius, 2003.

Grim, John A., \& Evelyn (ed), Mary, Agama, Filsafat dan Lingkungan Hidup, Yogyakarta: Kanisius, 2003.

Harun, Martin, Kata Pengantar; Agama Ramah Lingkungan, Jakarta: Paramadina, 2001.

Jurnal Ijtihad, vol. 10, Nomor 2, Salatiga: STAIN Salatiga, 2010.

Kàsir, Tafsir al-Qur'ān al-Azim, Ibnu, Jilid IV, Beirut: Dār al-Fikr, 1992.

Kuntowijoyo, Paradigma Islam Interpretasi Untuk Aksi, Bandung: Mizan, 1998. 
al-Mawdūdi, 'Alā, Abū, Khilafah dan Kerajaan; Evaluasi Kritis atas Sejarah Pemerintahan Islam, Bandung: Mizan,1994.

Nașr, Sayyed Ḥossein, Audrey R. Peterson Chapman, (eds), Consumption, Population and Sustainability: Perspectives from Science and Religion, Washington DC: Island Press, 2000., New York: Harper Collins Publisher, Inc., 2002.

Nasution, Harun, Akal dan Wahyu dalam Islam, Jakarta: UI Press, 1998.

Teologi Islam: Aliran-aliran Sejarah Analisa Perbandingan, Jakarta: Penerbit Universitas Indonesia, 2000.

Purba, Jonny, (ed.), Pengelolaan Lingkungan Sosial, Jakarta: Yayasan Obor Indonesia, 2005.

Al-Qarḍawi, Yusūf, Islam Agama Ramah Lingkungan, terj. Abdullah Hakam Syah dkk., Jakarta: Pustaka al-Kautsar, 2002.

al-Qurthubi, Abu Abdillah Muhammad Ibn Ahmad al-Ansharī, Jāmi' li Ahkām al-Qur'ān, Beirut: Dār al-Fikr al-'Ilmiyah, 1992.

Rahman, Fazlur, Islam, Terj. Ahsin Muhammad, Bandung: Pustaka, 1996.

Shabecof, Philip, A New Name for Peace; International Environmentalism, Sustanaible Development and Democracy, Hanover: University Press of New England, 1996.

Soemarwoto, Otto, Ekologi, Lingkungan Hidup dan Pembangunan, Jakarta: Djambatan, 1997.

Al-Syațibi, al-Muwafaqāt fi Ușūl al-Syarīah, ed. Khudari Husein, Jilid II, Beirut: Dar al-Fikr, 1341.

al-Ṭabari, Abū Ja'far, Jam̄’̀ al-Bayān fi Ta'wīl al-Qur'ān, t.t: Muasasah al-Risālah, 2000.

Zaid, Nașr Ḥāmid Abū, Mafhūm al-Naș; Dirāsah fi 'Ulūm al-Qur'ān Beirut: al-Markaz al-Saqafi al-'Arabỉ, 1994.

\section{Internet}

http//www.worldwatch.org/brain/features/timeline/timeline.html. http//www/grid.enuep.ch/geo/press.html. 